テクニカルノート

\title{
超低周波数領域のウイナースペクトルの測定
}

\author{
白 石 順二・畑川 政 勝 \\ 大阪市立大学医学部付属病院中央放射線部 \\ （論文受理 1988年12月 5 日） \\ （最終論文受理 1989年 5 月19日）
}

(Code No. 313)

Key words: Low frequency, Wiener spectrum, Microdensitometer

\section{METHOD OF MEASURING THE ULTRA-LOW FREQUENCY WIENER SPECTRUM}

\section{Junji Shiraishi and Masakatsu Hatagawa}

Department of Radiology, Osaka City University Hospital

(Article received; Dec., 5, 1988)

\section{Summary}

It is general knowledge that image noise from radiographic imaging system consist of quantum mottle, structure mottle and film graininess. Wiener spectrum is often used for an evaluation of the image noise, and it is usually measured in the frequency range above $0.1 \mathrm{cycle} / \mathrm{mm}$. However image noise may actually have, noises that exist in frequency range below $0.1 \mathrm{cycle} / \mathrm{mm}$ such as roller marks from film processors or pressure marks. In this study, we changed the optical systems of our microdensitometer to attach own scanning aperthure having $17 \mathrm{~mm}$ slit length and $0.7 \mathrm{~mm}$ slit width, and carried out investigating for measuring Wiener spectrum at ultra low frequencies. As a result, in the $0.06 \sim 0.1 \mathrm{cycle} / \mathrm{mm}$ frequency range, a rapid rising of the Wiener spectral value was observed. By comparing Wiener spectra of two types of film which having different sensitivities, it was considered that this rising was due to low frequency noise rather than quantum mottle.

\section{1.はじめに}

放射線画像系の粒状性，すなわちノイズ特性の評洒に はウイナースペクトルが多く用いられているッここれは ノイズ特性を，その成り立つ周波数成分ごとに記述でき るためである。

一般に，放射線画像系のノイズは，量子モトル，構造 モトル，フィルムの粒状性等から成り立つといわれてい
るが2)，これらは，通常約 $0.1 \mathrm{cycle} / \mathrm{mm}$ 以上の周波数領 域で測定されている。しかし，実際の画像には，自動現 像機のローラによるムラや, プレッシャマークなど, こ れらより低い周波数領域のノイズも含まれると考えられ る。また，これら以外に未知の低周波ノイズが含まれて いる可能性もあり, $0.1 \mathrm{cycle} / \mathrm{mm}$ 以下の周波数領域 (以 後, 超低周波数領域とする。)のウイナースペクトルを測 定することは，興味深いことである. 
こういった超低周波数領域のウイナースペクトルの測 定を行うとき，従来の方法では，スキャニングアパーチ ヤ(以後スリット) の長さと, 試料をスキャンする際の サンプリング距離との関係で，測定值に誤差が生じるた

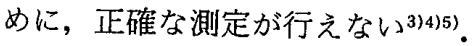

これらの問題点を避けるために，二次元走查によるス キャンデータを積算して，実質的にスリットの長さを長 くする方法 (synthesized slit 法) ${ }^{6)}$ や，スリットの長さが 有限であることから生じる誤差を補正する方法など6) が これまでに報告されている。

また, Wolf らは, $20 \mathrm{~mm}$ のスリット長さと, 必要とさ れるサンプリング距離を，1度のスキャンにより得られ る特殊な走査機構とを有するマイクロデンシトメータを 用いて，0.05 0.8 cycle $/ \mathrm{mm}$ の超低周波数領域のウイ ナースペクトルの報告を行っている7.

しかし，これらは特殊な装置を必要とするため，一般 的ではない. そこで, われわれは市販のマイクロデンシ トメータの光学系を, 通常の使用に問題がなく, 簡単に 超低周波数領域のウイナースペクトルの測定が行えるよ うに改造し，0.06 cycle $/ \mathrm{mm} \sim 1.0 \mathrm{cycle} / \mathrm{mm}$ のウイナ ースペクトルの測定を試み，有用な結果を得たので報告 する。

\section{2. 万法}

\section{1 スリットの長さとサンプリング距離の関係}

マイクロデンシトメータを用いて細長いスリットで測 定された一次元のウイナースペクトル $W^{\prime}(u)$ は実際に は二次元のスペクトルの断面 $W(u, 0)$ と考えられる.ま た, スリットの長さを $L$, 幅を $a$ としたとき, マイクロ デンシトメータの伝達関数 $T(u, v)$ は,

$T(u, v)=\operatorname{sinc}(a u) \operatorname{sinc}(L v)$

の式であらわされ，ここから一次元のウイナースペクト ル $W^{\prime}(u)$ と $W(u, 0)$ の関係は,

$$
\begin{aligned}
& W^{\prime}(u)=\frac{\operatorname{sinc}^{2}(a u)}{L} W(u, 0) \\
& W(u, 0)=\frac{L}{\operatorname{sinc}^{2}(a u)} W^{\prime}(u)
\end{aligned}
$$

の式で示される

スリットの長さ $L$ は, 測定するウイナースペクトルの 周波数領域 $U$ によって測定値に影響を及ほすが, 低周波 数領域における，両者の関係は

$$
U<1 / L
$$

であらわされ，この関係が成立する範囲で，正確な測定 が可能である7.
今回の実験ではマイクロデンシトメータのレンズ系を 使用せずに，照射および測光ツーブスに直接スリットを 取り付けることによって，スリットの長さを $17 \mathrm{~mm}$ まで 確保し，(4)式によって約 $0.06 \mathrm{cycle} / \mathrm{mm}$ 以上のウイナー スペクトルの測定を理論的に可能とした。

レンズ系を用いず自作のスリットを使用したので，実 際のウイナースペクトル測定にあたっては，自作のスリ ットの MTFを測定して補正をおこなった。このときの 補正式は

$$
W(u, 0)=\frac{L}{(\text { スリットの MTF })^{2}} W^{\prime}(u)
$$

で示される8).

一方, $0.01 \mathrm{cycle} / \mathrm{mm}$ の超低周波ウイナースペクトル を計算するために，1024点の FFTを用いる（後述）と， サンプリング間隔は $100 \mu \mathrm{m}$ となり, サンプリング距離 は, $1000 \mathrm{~mm}$ となる。

以上の条件で与えられる実効標準誤差は

$\left.S E=(X \cdot 1 / \delta x)^{-1 / 23}\right)$

$X$ : サンプリング距離 $\delta x:$ サプリング間隔 の式で示され, 本法では, 約 $1 \%$ の誤差となった.

ここで, 試料をサンプリングするときのサンプリング 間隔 $\delta x$ と求められる最大周波数 $u_{\max }$ の関係は

$$
u_{\max }=\frac{1}{2 \delta x}
$$

の式であらわされる9).

\section{2 実験方法}

自作スリットの本体は, 直径 $20 \mathrm{~mm}$ のプラスチック製 パイプで製作した.スリット部は加工のしやすさから選 択した鉛箔をアクリル板に張った後，スリット状にカッ トした．自作スリットは照射用の $1 \times 17 \mathrm{~mm}$ のスリット と, 測光用の $0.7 \times 17 \mathrm{~mm}$ のスリットで,これらをマイク ロデンシトメータの試料テーブルの上下にある対物レン ズをはずしたあとに，スリットの中心が光軸線上にくる ように固定した（Fig. 1，2，3)。また，スリット中心の 微調整は装着後, 付属のレンズ台の微調整つまみにより 行った.このとき，スリット一試料間の距離は約 $0.5 \mathrm{~mm}$ とし，外部からの光の進入をなくすために，測定時は室 内の照明を最小限度に落とした。なお，ピントの調整に ついては，レンズ系を使用していないため必要がなかっ た.

また，光源に従来の装置のものをそのまま使用したの で, 照射電球のフィラメントの形状が光分布にムラを生 じ，これを除去するために測光サイド側のスリットには オパールグラスを装着した。 


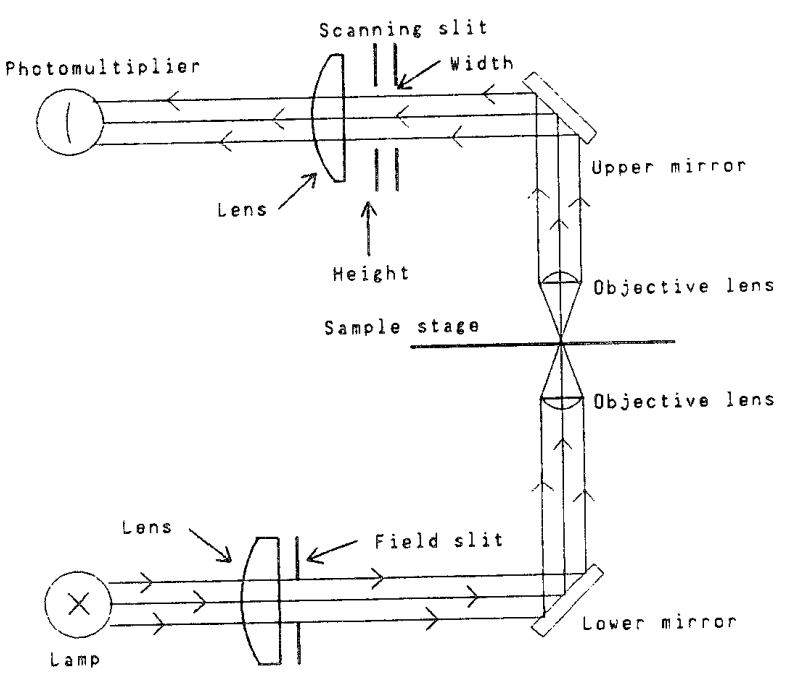

Optical system of normal microdensitomer

a. original system (befor change)

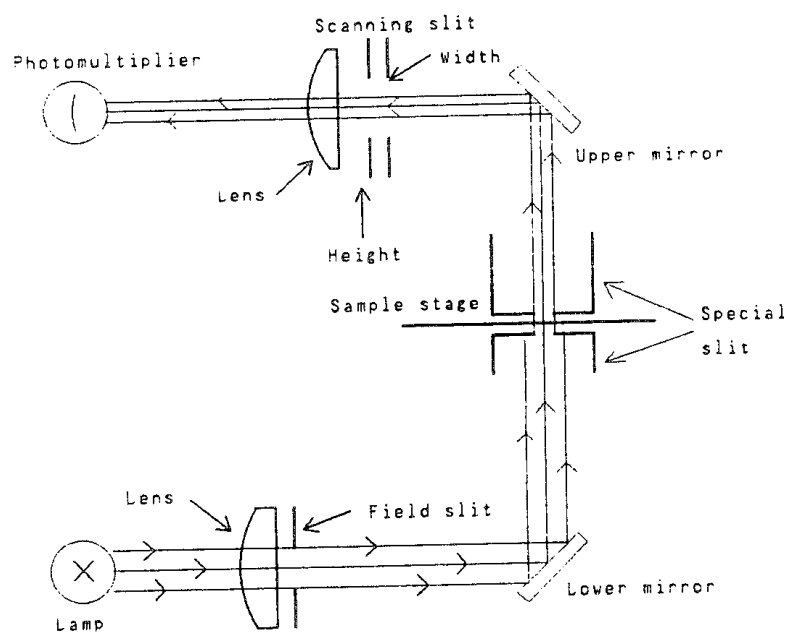

Optical system of improvement micradensitometer

b. improved system (after change)

Fig. 1 Optical systems of microdensitometer.

自作スリットの長さは，もとの対物レンズ取り付けツ ーブスのサイズの関係で最大の $17 \mathrm{~mm} に$ によたスリット 幅は，光電子増倍管への入力がレンズ系を使用していな いことから，幅が狭すぎると光量不足を生じ測定不能と なるため，測定可能な最低幅である $0.7 \mathrm{~mm}$ とした。

また，自作スリットの MTFは，マイクロデンシトメ ータで普通用いられる，ナイフエッジをもちいた方法で 湘定した8)。

試料作製には，当院の一般撮影系で，通常使用してい る Du Pont 社 Quanta Fast Detail の増感紙と, フィル ムCronex-4, Cronex-7 の組み合わせを用いた。両フィ ルムとも，半切サイズのカセッテを使用し FFD $220 \mathrm{~cm}$
ORIGIUAD DOS -15

IMPROVED PES-15

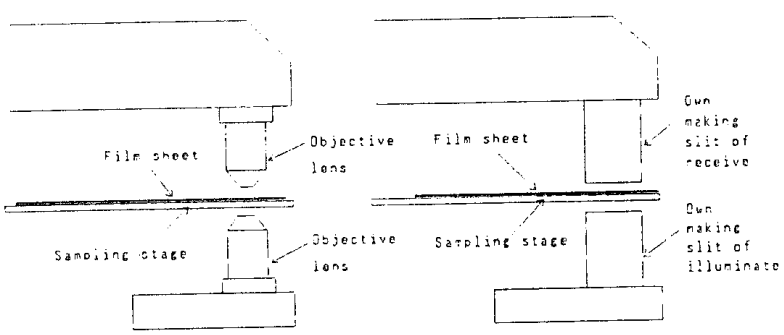

Fig. 2 Illustrations of the set up our slit.
a. original system
b. improved system

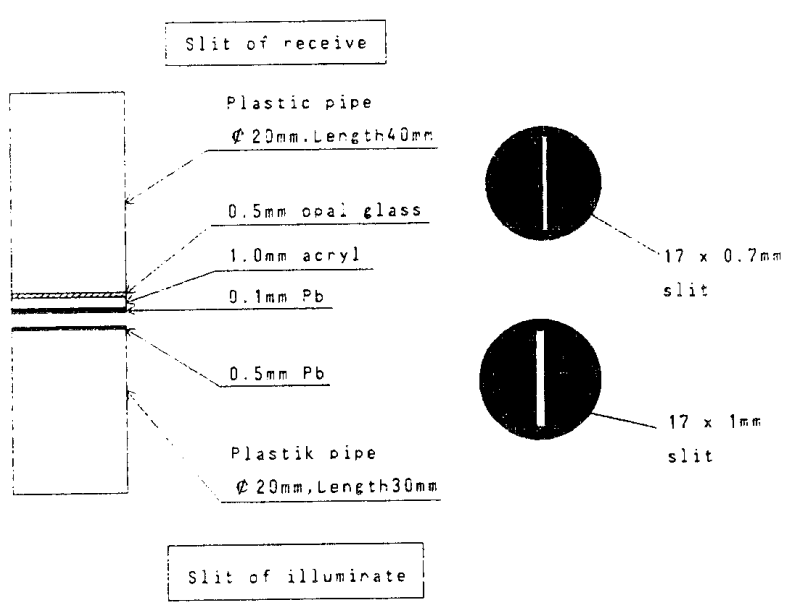

Fig. 3 Structure of our slit.

で濃度が $1.0 \pm 0.02$ にるよう露光を与えた。このとき， 半切サイズ全面について，前記の濃度範囲におさまるよ うに特に注意して試料を作成した。

スキャンは，フィルムのサンプリング距離 $(1000 \mathrm{~mm})$ がテーブルの移動距離 $(350 \mathrm{~mm})$ より長いために，スリ ットの長軸方向に少しずつシフトさせながら試料テーブ ルを 3 回往復させて行った（Fig.4）.

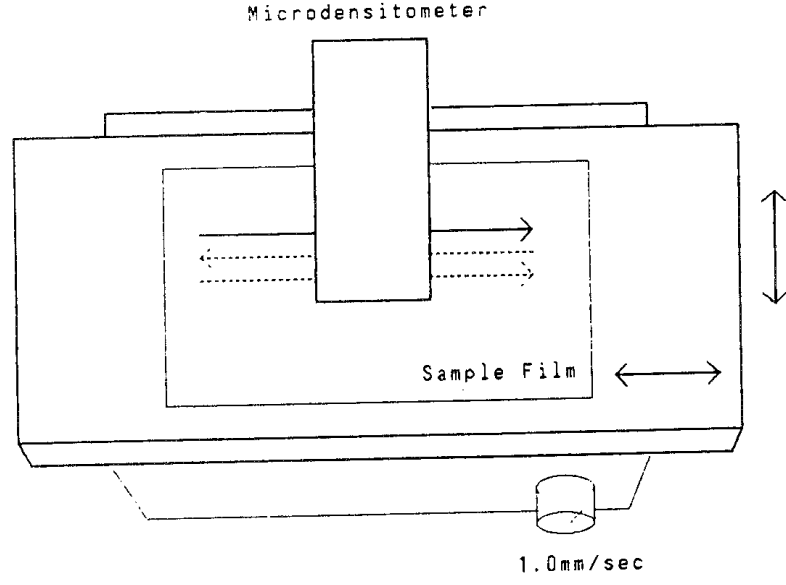

Fig. 4 Scanning method of sample. 


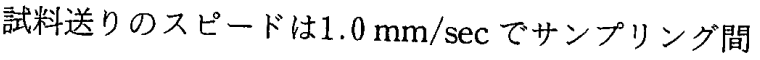
隔は $100 \mu \mathrm{m}$ である。

また, スキャンと同時にXYレコーダで波形を記録 し，スキャン全域にわたって，X線管のヒール効果によ るトレンドの有無を確認し，このトレンドの認められた データについてはスキャンをやり直した。

得られたデー夕は, 一旦, MZ-2000に取り込んだ後, PC-9801に転送した.ウイナースペクトルの計算は, 当 院で使用している計算プログラムを用いた。これは，ス キャンデータからの取り込みや計算が, 通常の方法で, 簡便に行えるためである。われわ㣗のウイナースペクト ル測定法ならびに計算法はBRHレポート,および, 日放 技の委員会報告 “放射線画像系の粒状性の湘定法” に準 ずるものである51101111. 使用機器は, マイクロデンシトメ 一タがサクラ PDS-15, A-D コンバータがカノープス電 子CAD-12-4 である。サンプリング間隔は, 通常の測定 ではテーブル送り早さが $0.1 \mathrm{~mm} / \mathrm{sec}$ なので, $10 \mu \mathrm{m} て ゙$ あるが，今回の測定ではサンプリング間隔を $100 \mu \mathrm{m}$ と

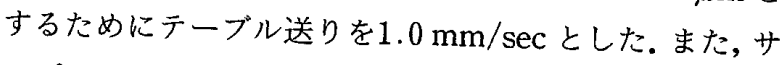
ンプリング数は通常の測定と同様に約 10,000 点である. デー夕は 2 点スムージングの後, 18セグメントの1024点 のデータを高速フーリエ変換 (FFT) し, 次に18の FFT 結果をアンサンブル平均して，1回スキャンの測定值と した。このスキャン一計算をフィルムの場所を変えて10 回行い, その平均を 4 次式で近似して最終值とした。 な お，計算によるトレンド処理は行わず，拡散光濃度への 変換係数 Qファクタによる変換も行わなかった。

また比較のため, 自作スリットではなく従来より使用 しているレンズ系を用いて，スリットサイズを最高の長 さ $2 \mathrm{~mm}$ 幅 $50 \mu \mathrm{m}$ に設定し, その他はすべて本法と同じ 条件で測定を行った（ただし，Qファクタの補正は行っ た).

\section{3. 結果}

Fig. 5 には自作スリットの MTF を示す. 理論的に, ス

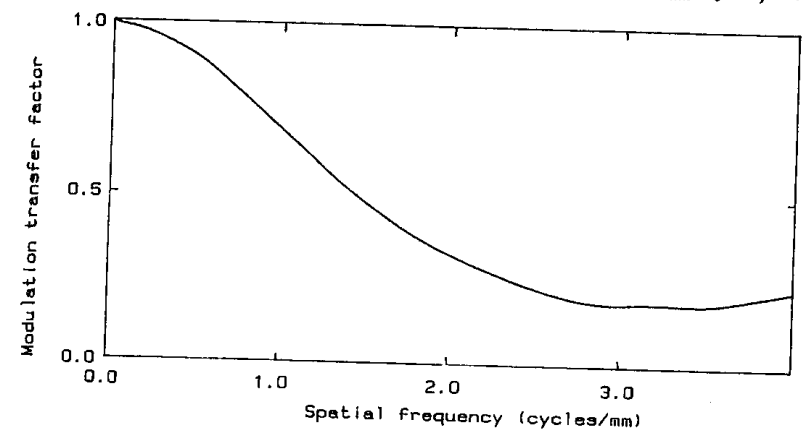

Fig. 5 Moduration transfer function of our slit.
リットの幅が $0.7 \mathrm{~mm}$ の場合, スリットの MTFは約 1.4 $\mathrm{cycle} / \mathrm{mm}$ で 0 になる.しかし, 本法では, 光源の光分布 の不均一により, 全領域において MTF は理論値より高 い值を示した。

Fig. 6 は，今回の測定で得られた自作スリットを用い たときと、レンズを用いたときの超低周波数領域のウイ ナースペクトルを示している、レンズを使用したときは (3)式によって補正を抗こなったが，自作スリットを求め たものより低い値を示した。 今回の実験においては，測 定値の信頼性は $0.06 \mathrm{cycle} / \mathrm{mm}$ 以上であるが, 計算プロ グラム上, $0.01 \mathrm{cycle} / \mathrm{mm}$ まで算出が可能であった。

Fig. 7 は自作スリットを用いて求めたCronex-4と Cronex-7 のウイナースペクトルを示している，超低周 波数領域では両者に大きな差はみられず，ともにこの領 域での低周波ノイズによる立ち上がりがみられた。

Fig. 8 は, 従来の方法で得られたウイナースペクトル と, 今回の実験で得られた超低周波数領域のウイナース ペクトルを示している. Cronex-4, Cronex-7 ともに0.5 cycle $/ \mathrm{mm}$ 付近では, 従来の方法で得られた值と近い値 を示し，その結合が可能であると考えられる。

\section{4. 考察}

予備実験中に，スキャニングデータが, 長いサンプリ

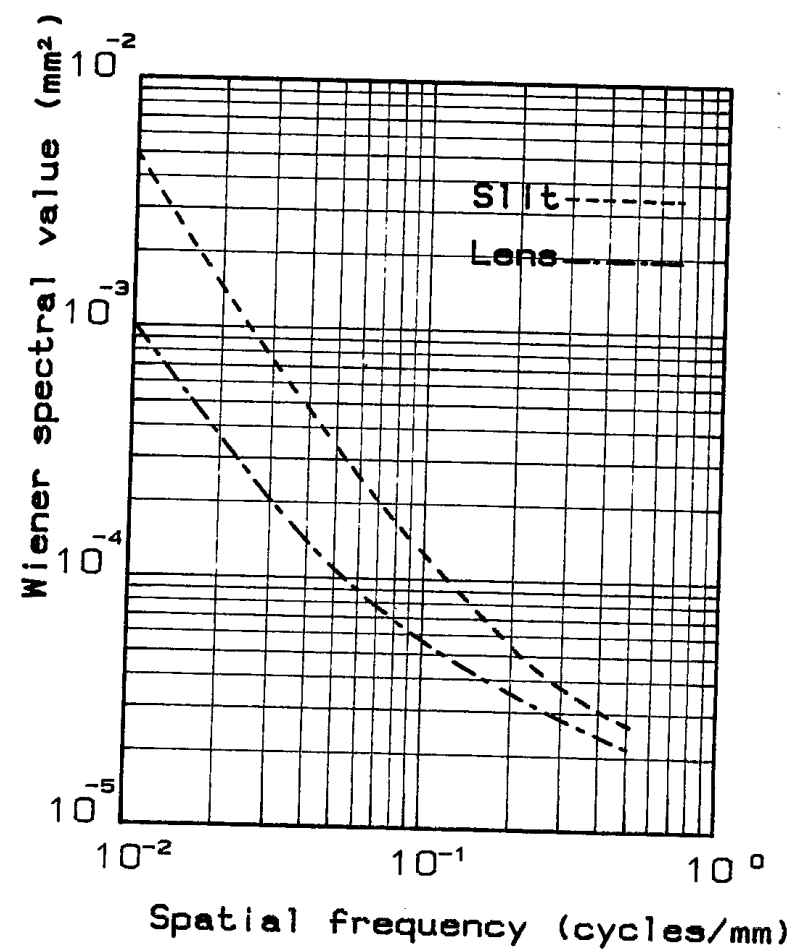

Fig. 6 Wiener spectra at low frequencies obtained by using our slit and regular aperture for Cronex7/QFD 


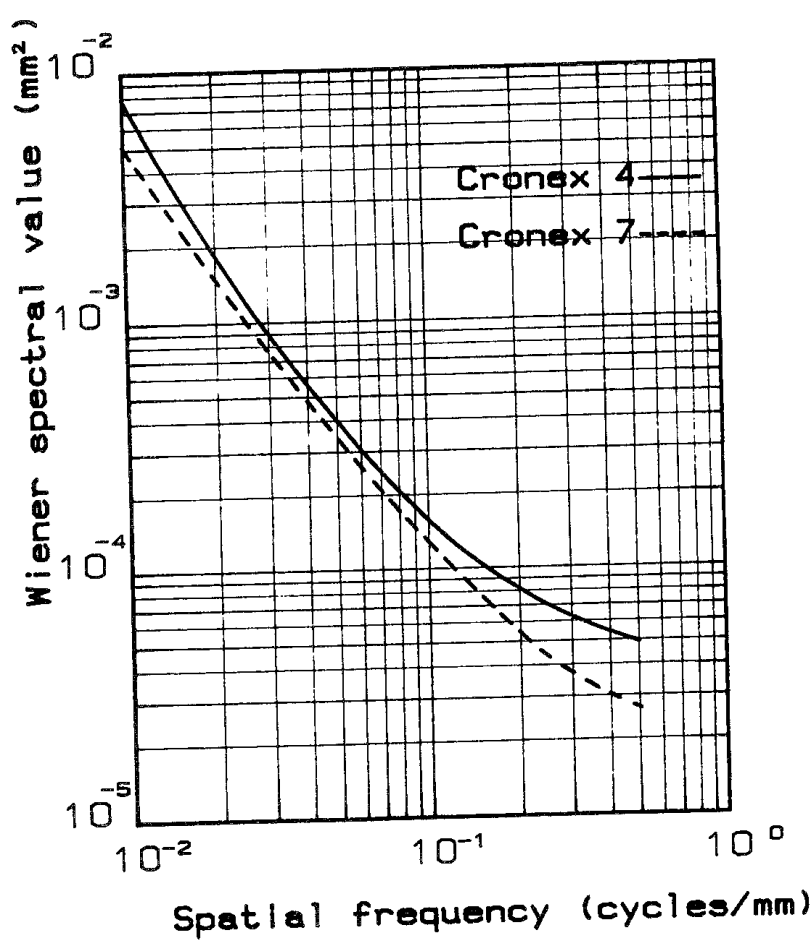

Fig. 7 Wiener spectra at low frequencies obtained with our slit for Cronex 4 and Cronex 7

ング距離のために，X線管焦点の強度分布によるトレン ドの影響を受けることが判明した。そのため，本実験に おいては,試料の濃度がフィルム全面にわたって一定（士 0.02）となるようにした。これは，増感紙一フィルム系 および現像以外のファクタをノイズ要因から除去するた めである。

また，スキャニングテーブルの移動距離の関係から， 1 回のスキャンにつきテーブルを 3 回往復させているの で，その切り替えの際に，濃度の不自然な変動が泥入し 測定誤差を生じた。このため，サンプリング距離を短く することも考えられたが，従来の測定装置，計算プログ ラムを用いて測定することを今回の実験の目的としたの で，プログラム変更はしなかった。

マイクロデンシトメータの光電子増倍管は, 平行光測 光であったが，レンズ系を取り外したので拡散光測光と 考え，Qファクタによる補正は行わなかった。

今回の実験により得られた測定結果では，Wolfらの 報告と同様に，超低周波数領域でウイナースペクトルが 高い值を示した。また，Fig.6に示されるように、レンズ を用いた方法でも同様の傾向を示した。自作スリットと レンズを用いた方法で差が生じたのは，レンズを用いた 方法ではスリットの長さが足りなかったためであろう。

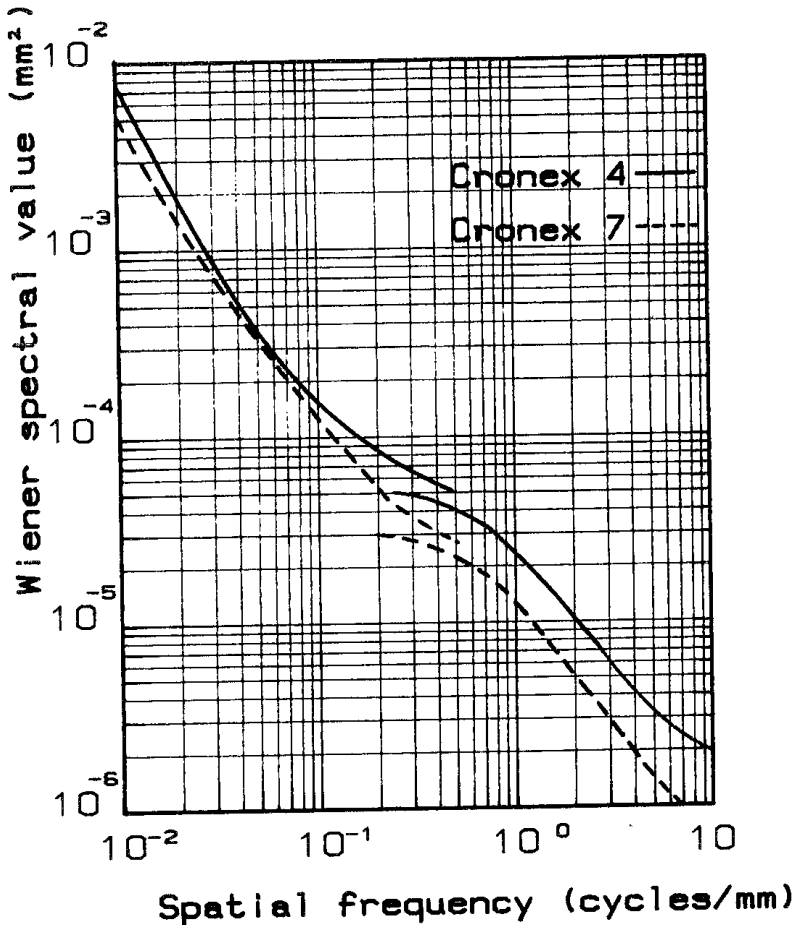

Fig. 8 Wiener spectra of Cronex 4 and Cronex 7 systems in the low frequency range obtained with our slit and those at usual frequency range obtained with regular aperture.

次に，従来の方法で測定した $0.1 \sim 1.0 \mathrm{cycle} / \mathrm{mm}$ のウ イナースペクトルと，本法で測定した超低周波数領域の ウイナースペクトルとを比較すると，0.5 cycle $/ \mathrm{mm}$ 付 近に㭁いて非常に似た值を示し, 結合可能であると考え られる (Fig. 8)。

一般に，量子モトルのウイナースペクトルはMTFの 自乗に比例するため，周波数軸に対しほぼフラットであ る2)。しかし，超低周波数領域ではわれわれの測定したウ イナースペクトルは高い值を示した。これは，量子モト ルの上にさらに何らかの濃度変動, 例えば自動現像機の ローラによる濃度ムラやプレッシャマークなどの変動が 加わっているものと考えられる。またこの領域で， Cronex-4 と Cronex -7 という感度の異なるフィルムが, 同様な值を示したのは，フィルムの構造によるものや， 量子モトルによる変動よりも，それ以外の前述のような ファクタによって変動する成分の方が多いからであり, それに対して $0.5 \mathrm{cycle} / \mathrm{mm}$ より上の領域では, それら より量子モトルによる影響の方が強く現れていることを 示している。

このような超低周波数領域での濃度変動をどのように 
評価するかは今後の問題であり，一般の画像評価として は, $0.1 \mathrm{cycle} / \mathrm{mm}$ 以上で十分であると考えられる。

\section{5. 結語}

市販のマイクロデンシトメータのスキャニングアパー チャに, 自作のスリットを取り付けるという簡単な改造 によって，超低周波数領域のウイナースペクトルの測定 を行うことができた. その結果，超低周波数領域ではウ イナースペクトル值が，急激に高くなることがわかった。 したがって，この測定法はプレッシャマーク，その他の 低周波数ノイズの定量測定に有効であるという結論を得 た。

最後に, 今回の実験, 発表にあたって適切な助言をいただい た当大学非常勤講師光田秀雄氏に感謝します.

\section{文献}

1）内田 勝, 山下一也, 稲津 博 : 放射線画像情報工 学 (1), p. 223-233, 通商産業研究社, (1980).

2) Rossmann $K$ : Spatial fluctuations of $x$-ray quanta and the recording of radiographic mottle. Am. J. Roentgenal., Rad. Therapy \& Nuclear Med., 90, 863-869, (1963).

3) Sandrik JM, Wagner RF : Radiographic screenfilm noise power spectrum: variation with microdensitometer slit length. Appl. Opt., 20, 2795-
2798, (1981).

4）「放射線写真のスクリーンーフィルム系の MTF と ウイナースペクトル」.日放技学誌, 39(3), 240-270； $39(4), 426-447$, (1983).

5）「放射線画像系の粒状性の測定法（I）（II）」. 日放 技学誌，43(12)，1743-1768，(1987）；44(1)，4462 (1988).

6) Koedooder K, Strackee J, Venema HW : A new method for microdensitometer slit length correction of radiographic noise power spectra. Med. Phys., 13, 469-473, (1947).

7) Wolf $M$, Angerstein W : Low-frequency Wiener spectra of radiographic screen-film systems. Phys. Med. Biol., 32, 557-564, (1987).

8) Dainty JC, Show R: Image science, Academic Press, p. 276-319, (1974).

9) Dainty JC, Show R: Image science, Academic press, p. 190-231, (1974).

10）畑川政勝, 他：散乱線, 管電圧, 被写体厚が増感紙 一フィルム系の粒状性におよぼす影響。日放技学誌， 43(12), 1721-1727, (1987).

11) Doi K, Holje G, Sandrik JM, et al : MTF's and Wiener spectra of radiographic screen-film systems. HHS Publication, FDA 82-8187, 1, (1982). 